\title{
Response of Polycrystalline Solar Cell Outputs to Visible Spectrum and other Light Sources-a Case Study
}

\author{
Ayman Y. Al-Rawashdeh ${ }^{1}$, Omar Albarbarawi ${ }^{2}$, Ghazi Qaryouti ${ }^{3}$ \\ 1,2Department of Electrical Engineering, Al-Balqa Applied University, Jordan \\ ${ }^{3}$ Department of Mechatronics Engineering, Al-Balqa Applied University, Jordan
}

\begin{abstract}
Article Info
Article history:

ABSTRACT

Received Des 23, 2017

Revised Jun 2, 2018

Accepted Jun 25, 2018

\section{Keyword:}

Artificial radiation

Indoor solar cells

Polycrystalline solar cells

Solar radiation

Visible radiations

In this case study, two polycrystalline solar modules were installed outdoors (irradiated by sunlight) and indoors (irradiated by artificial lights). The solar cells in both cases were installed using different color filters that allowed the passage of certain light frequencies. The amount of energy produced by each module were measured and compared to a reference module with no filter. The results indicated the variable response of polycrystalline solar cells to natural and artificial light sources, being more responsive in both cases to red band color as could be deduced from their $\%$ current outputs $(72.5 \%$ sunlight radiation; $84.38 \%$ artificial light sources). Other colors, including yellow, green, orange and violet afforded acceptable outputs. The results indicated that electrical outputs of indoor solar cells decreased when colored filters were used, but red filter in general afforded the maximum outputs, for both the artificially radiated indoor and naturally radiated outdoor solar cells. The case study suggests the possible complementary advantage of using indoor mounted solar cells for the production of electricity during artificial illumination period of the day.
\end{abstract}

Copyright $@ 2018$ Institute of Advanced Engineering and Science. All rights reserved.

\section{Corresponding Author:}

Ayman Y. Al-Rawashdeh, Department of Electrical Engineering, Al-Balqa Applied University,

P.O. Box: 15008, Amman 11134, Jordan.

Email: dr.ayman.rawashdeh@bau.edu.jo

\section{INTRODUCTION}

Fossil fuels, including coal, petroleum and natural gas are the main sources of energy, but these resources are limited. Therefore, there is a requirement of alternative energy sources to provide us clean, low cost and renewable energy. Light in general, regardless of its source (natural or artificial) is a main promising source of renewable energy which can be converted into electrical energy by solar panels with low coast. In addition, this source of energy has minimal ecological impact causing no pollution. Moreover, the low maintenance coast and long life duration of the solar cells makes them desirable for use by ordinary people and homeowners.

Solar cell panels are used to convert solar light energy into electrical one [1],[2]. The first solar panels, based on polycrystalline silicon (known also as polysilicon (p-Si)), were introduced to the market in 1981. These solar panels did not require the Czochralski process. This type of solar cells is known to have many advantages. In addition of their simple low cost manufacturing process [3], polycrystalline solar cell panels are known for their low heat tolerance [4] as compared to other types. Moreover, this type is known for their mixed PV applications indoors and outdoors with an efficiency of about 13-14\% as compared to other types [5].

Due to the advantages of the polycrystalline solar cell panels, the current study was designed to investigate their response to visible spectrum and other light sources (natural and artificial). The performance 
of the polycrystalline solar cells is analyzed by calculating the output power in the presence and absence of colored filters. Literature survey reveals that the performance of solar cells is dependent on outputs to visible spectrum and other light sources [6]. However, since indoor light lamps generate copious amounts of visible radiation spectrum that could be beneficial for the production of electricity, the current investigation describes the possible advantage of indoor mounting of polycrystalline solar cells to use artificial lightning for the production of electricity [7].

\section{RESEARCH METHOD}

\subsection{Mathematical Description}

The theory of the photoelectric effect explains the experimental observations of the emission of electrons from a given metal. Where Einstein described the photoelectric effect by using a formula that relates the maximum kinetic energy $\left(K_{\max }\right)$ of the photoelectrons to the frequency of the absorbed photons $(f)$ and the threshold frequency $\left(f_{0}\right)$, where $\left(f_{0}\right)$ is a certain minimum frequency of incident radiation below which no photoelectrons are emitted.

The maximum kinetic energy of the emitted photoelectron depends on the frequency of the incident light, it must be above the threshold frequency, but it is independent from the intensity of the incident light on the surface of a metal. The rate of the magnitude of the photoelectric current is directly proportional to the intensity of the incident light

$$
K_{\max }=h\left(f-f_{0}\right) \text { or } K_{\max }=E-\phi \text {, }
$$

Where

$$
E=h f=h c / \lambda, \text { and } \phi=h f_{0}=h c / \lambda_{0} .
$$

$h$-Planck's constant $=6.626 \times 10^{-34}$ joules. $E$ - Energy of the absorbed photons, with frequency $\left(f_{0}\right)$ or wavelength $(\lambda)$, and the $(\phi)$ work function of the surface with threshold frequency $\left(f_{0}\right)$ or threshold wavelength $\left(\lambda_{0}\right)$

$$
V_{0}=W / q=K_{\max } / e
$$

Thus, $\quad K_{\max }=e V_{0}$

The maximum kinetic energy ( $K_{\max }$ ) of the photoelectrons -with charge (e)- can be determined from the stopping potential $\left(V_{0}\right)$. When charge (e) is given in coulombs, the energy will be calculated in joules. When charge (e) is given in elementary charges, the energy will be calculated in electron volts. Each electron passing through the circuit is carrying a very small amount of energy. However, by collective effort, electrons can transport a tremendous amount of energy. The amount of energy transferred by an electrical circuit depends on the quantity of electrons and the energy carried by each electron. The electromagnetic spectrum can be classified and arranged in respect to their various wavelengths/frequencies. Table 1 shows this spectrum, which consists of all the types of electromagnetic radiation from the frequency of ultraviolet (UV) rays, visible spectrum, to Infrared rays. The different wavelengths of the visible light are shown in

\begin{tabular}{|c|c|c|c|c|}
\hline Color & Wavelength (nm) & Frequency & Photon energy $(\mathrm{eV})$ & $\%$ of sunlight \\
\hline Ultraviolet & $10-380$ & $800 \mathrm{THz}$ to $30 \mathrm{PHz}$ & $3.3-124$ & $46 \%$ \\
\hline Violet & $380-450$ & $668-789 \mathrm{THz}$ & $2.75-3.26$ & \multirow{6}{*}{$7 \%$} \\
\hline Blue & $450-495$ & $606-668 \mathrm{THz}$ & $2.50-2.75$ & \\
\hline Green & $495-570$ & $526-606 \mathrm{THz}$ & $2.17-2.50$ & \\
\hline Yellow & $570-590$ & $508-526 \mathrm{THz}$ & $2.10-2.17$ & \\
\hline Orange & $590-620$ & $484-508 \mathrm{THz}$ & $2.00-2.10$ & \\
\hline Red & $620-750$ & $400-484 \mathrm{THz}$ & $1.65-2.00$ & \\
\hline Infrared rays & $750-1000,000$ & $430 \mathrm{THz}-300 \mathrm{GHz}$ & $1.24 \times 10^{-3}-1.75$ & 47 \\
\hline
\end{tabular}
Table 1.

Table 1. The Electromagnetic Spectrum 


\subsection{Materials and Methods}

The electrical specifications of the seven-polycrystalline silicon solar cells used in the current study are listed in Table 2. The experiment was performed under clear sky without clouds. The cells were adjusted for optimum use and were tilted every one hour to trace the sunlight and achieve maximum exposure during the day and according to the procedure described in the literature [7]. Measurements of solar irradiance and electrical parameters were recorded using a solar power meter (digital Ampere meter, a protractor, digital voltmeter, Lux meter, wattmeter, thermometer, resistor $(0.25 \mathrm{ohm} 4$ watt). Each solar cell was mounted on a wooden cube.

Table 2. Electrical Specifications of the Polycrystalline Silicon Solar Cells 156x156 mm Model SPM050-P and the Experimental Parameters of the Solar Module Employed for Polycrystalline Solar Cells

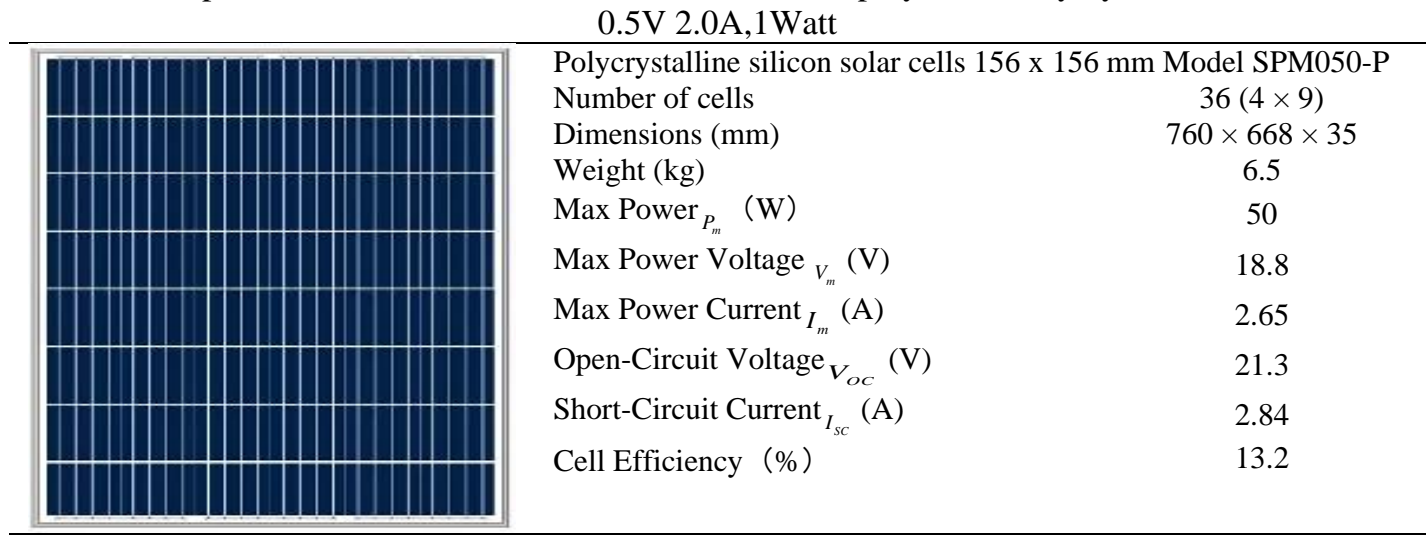

For determining the effect of using artificial light sources on the outputs of solar cells, incandescent lamp $(100 \mathrm{~W})$ and LED lamp (12 and $15 \mathrm{~W})$ were mounted at constant distance from the solar cells and the electrical parameters were measured. The experiment was repeated with the use of different filters and the $\%$ current output was determined according to equation (4).

$\%$ Current Output=(Filter Current/No Filter Current $) \times 100 \%$.

\section{RESULTS AND ANALYSIS}

\subsection{Effect of sunlight on the solar cell outputs}

This experiment was performed on the clear sky of June, $13^{\text {th }}, 2017$, in Amman city. Measurements were recorded every one hour. The results clearly indicated the effect of sunlight frequency on the response of the solar cells [8]. However, the intensity of radiation did not affect the output response of the investigated solar cells. Results for the outputs of the solar cells during this study are summarized in Table 3 and are represented graphically in Figure 1. As shown in Table 3, the highest output readings of short circuit currents were recorded at midday, the maximum current increased linearly with increasing light intensity. The voltage decreased with increasing temperature, particularly at midday.

Table 3. Solar Cell Outputs during a Sunny Day

\begin{tabular}{ccccc}
\hline Time & Voltage $(\mathrm{V})$ & Current $(\mathrm{mA})$ & Lighting intensity $($ Klux $)$ & Temperature $\left({ }^{\circ} \mathrm{C}\right)$ \\
\hline 6:00 AM & 6.98 & 11.00 & 3762 & 13 \\
7:00 AM & 7.41 & 15.61 & 4881 & 13 \\
8:00 AM & 7.44 & 29.89 & 1334 & 27 \\
9:00 AM & 7.43 & 48.00 & 25726 & 27 \\
10:00 AM & 7.35 & 60.00 & 85745 & 27 \\
11:00 AM & 7.33 & 69.00 & 85745 & 33 \\
12:00 PM & 7.22 & 75.00 & 85745 & 33 \\
1:00 PM & 7.20 & 74.00 & 85745 & 33 \\
2:00 PM & 7.18 & 71.00 & 85745 & 36 \\
3:00 PM & 7.19 & 62.00 & 85745 & 37 \\
4:00 PM & 7.18 & 49.00 & 8746 & 37 \\
5:00 PM & 7.16 & 34.00 & 6008 & 34 \\
6:00 PM & 7.05 & 18.00 & 3734 & 34 \\
\hline
\end{tabular}

Int J Elec \& Comp Eng, Vol. 8, No. 6, December 2018 : 4096 - 4103 


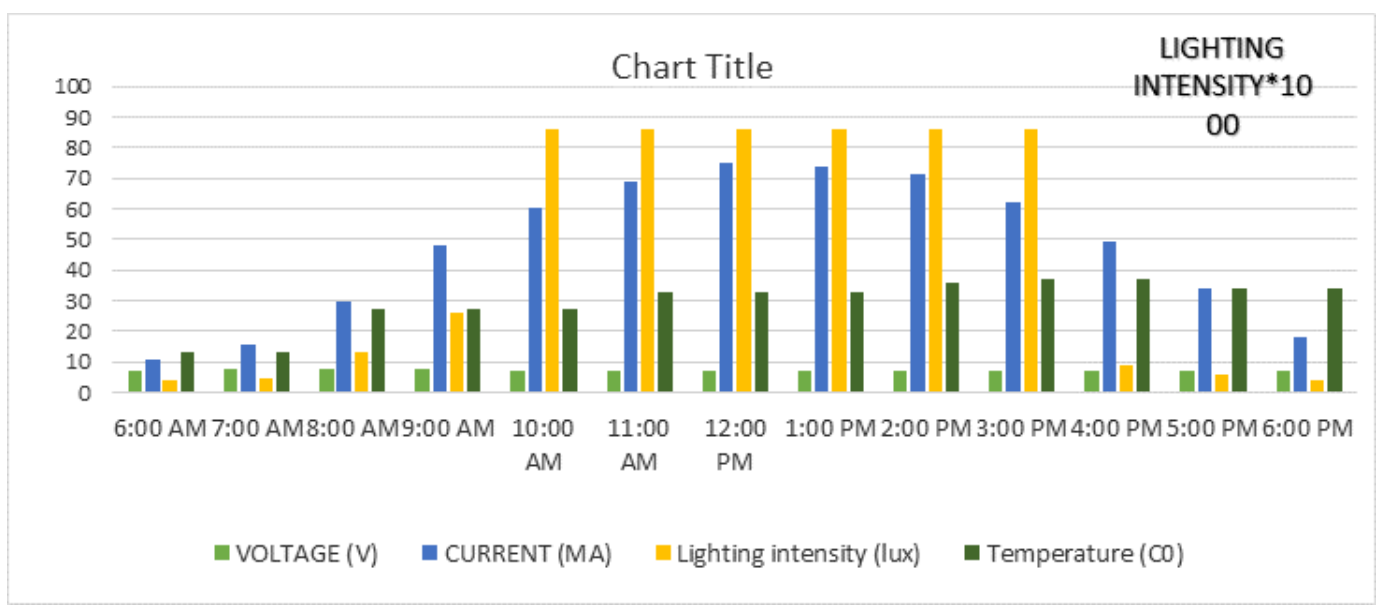

Figure 1. The light intensity, current, voltage and temperature outputs

\subsection{The effect of different angles of incidence of sunlight throughout the day on a solar cell}

In an attempt to determine the effect of the angle of incidence of sunlight on the efficiency of the polycrystalline solar cells [9], the assemblies shown in Figure 2, where used at the time that afforded the maximum current output (12:00 o'clock), when the light incident angle is perpendicular to the solar cell. The solar cells were mounted on wooden cubes at different angles.

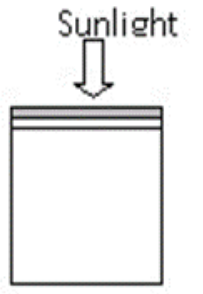

$90^{\circ}$ to sunlight

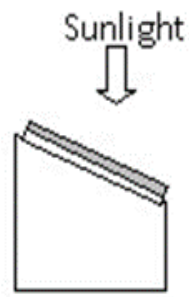

$75^{\circ}$ to sunlight

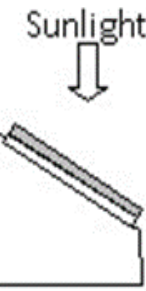

$60^{\circ}$ to

sunlight

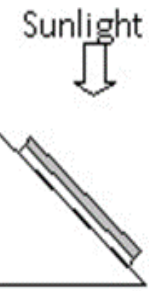

$45^{\circ}$ to

sunlight

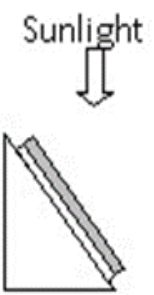

$30^{\circ}$ to sunlight

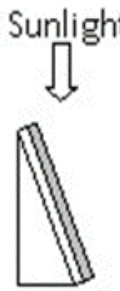

$15^{\circ}$ to

sunlight

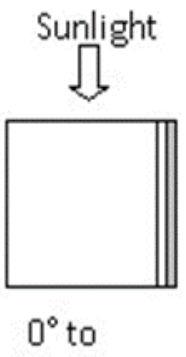

sunlight

Figure 2. Mounting the solar cell at different angles onto a wooden block.

The outputs of the polycrystalline solar cells as a function of the light incident angle are listed in Table 4. The results revealed that the solar cell mounted perpendicular to the sunlight had excellent outputs in terms of voltage and current, as shown in Figure 3. However, these outputs declined as the angle reduces to zero. Again, the obtained results were in total agreement with those listed in the literature [10], [11] which suggests the use of a solar tracker system to obtaining the maximum efficiency and power outputs of the employed solar panel [12].

Table 4. The Experimental Outputs (V, I and P) of the Polycrystalline Solar Cells Module Measured as a Function of Light Incident Angle

\begin{tabular}{cccc}
\hline Light incident angle & Voltage $(\mathrm{V})$ & Current $(\mathrm{mA})$ & Power $($ Watt) \\
\hline $90^{\circ}$ & 7.50 & 50.00 & 0.3750 \\
$75^{\circ}$ & 7.37 & 40.50 & 0.2985 \\
$60^{\circ}$ & 7.17 & 40.00 & 0.2868 \\
$45^{\circ}$ & 7.00 & 39.00 & 0.2730 \\
$30^{\circ}$ & 6.62 & 38.50 & 0.2548 \\
$15^{\circ}$ & 6.25 & 38.00 & 0.2375 \\
$0^{\circ}$ & 5.87 & 37.62 & 0.2208 \\
\hline
\end{tabular}




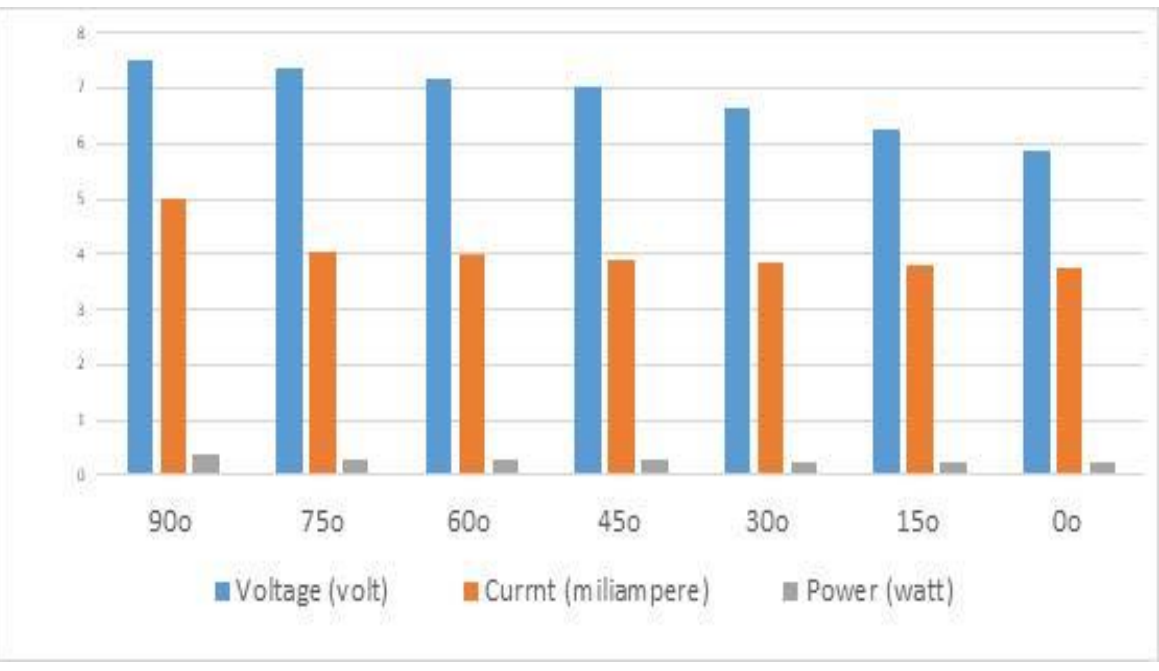

Figure 3. The output power at different angles of incidence of solar rays at different angles

\subsection{Light Color Effects on the Solar Cell Outputs}

Semiconductors from which solar cells are made respond to light bands on their energy gaps. There is no single semiconductor that has an energy gap designed for responding to the full range of sun light, from the infrared through visible light and the high energy ultraviolet radiation. Hence, one of the major advances in this area is to design a full spectrum semiconductor suitable for solar cell applications. Since the available cells respond differently to different colors, the current investigation was designed to investigate which color could mostly affect the electrical outputs of the polycrystalline solar cells. Colored filters (including red, orange, yellow, green, blue and violet filters, as shown in Figure 4 were used [13]. The procedure was designed to measure the short-circuit currents and the open-circuit voltages of the cells. The solar cells outputs were also determined in the absence of the colored filter and were used to measure the $\%$ current output according to equation 4 [14]. Results are summarized in Table 5.
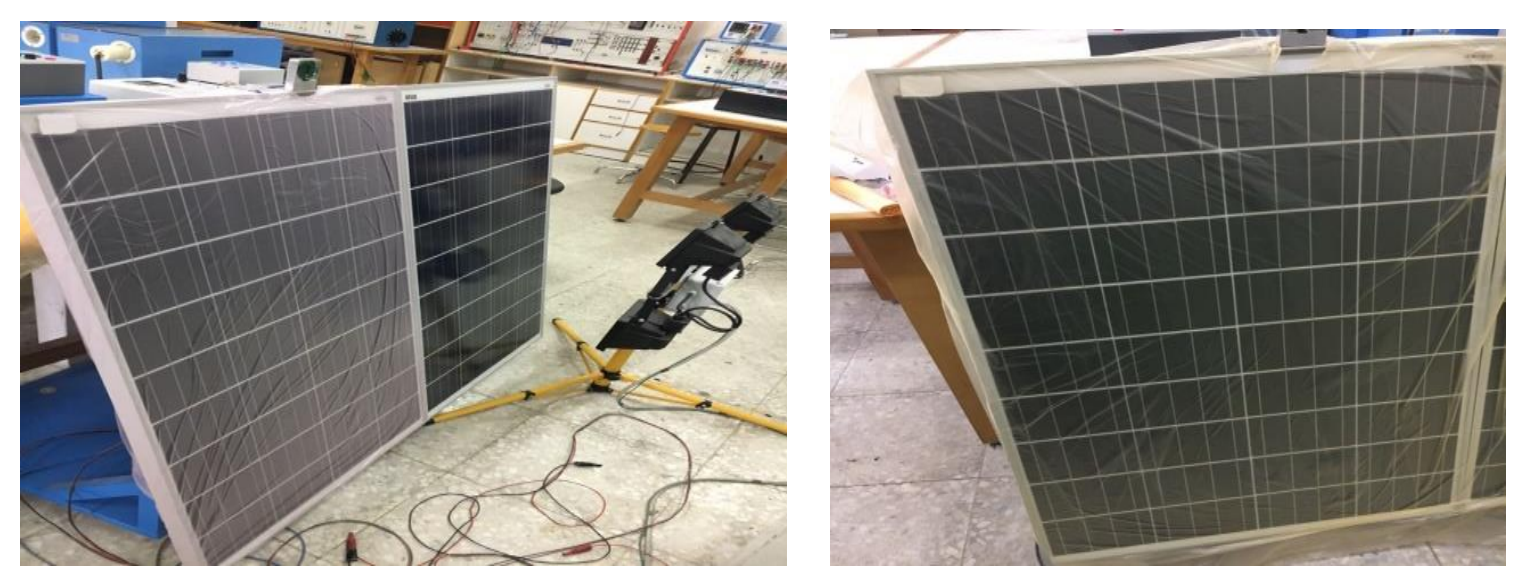

Figure 4. Polycrystalline solar cell with filters

Table 5. Effect of Color-filter on Cell Output Using Sunlight

\begin{tabular}{cccccc}
\hline Filter & Wave length $(\mathrm{nm})$ & Current $(\mathrm{mA})$ & Voltage $(\mathrm{V})$ & Power $(\mathrm{W})$ & \% Current output \\
\hline Red & $625-780$ & 36.25 & 7.10 & 25.70 & 72.50 \\
Orange & $455-495$ & 15.71 & 6.65 & 10.45 & 31.40 \\
Yellow & $595-625$ & 27.22 & 7.05 & 19.19 & 54.44 \\
Green & $575-595$ & 33.93 & 7.09 & 24.09 & 67.86 \\
Blue & $495-575$ & 15.2 & 6.3 & 9.60 & 30.40 \\
Violet & $390-455$ & 22.39 & 6.80 & 15.23 & 44.78 \\
Without filter & $390-780$ & 50.00 & 7.51 & 37.55 & 100.00 \\
\hline
\end{tabular}

Int J Elec \& Comp Eng, Vol. 8, No. 6, December 2018 : 4096 - 4103 


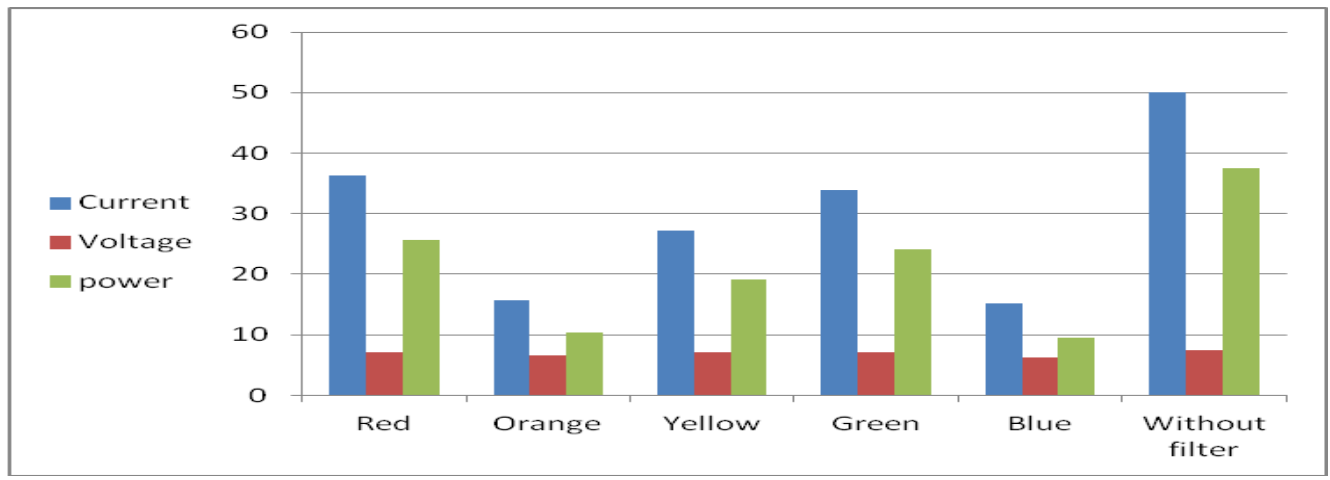

Figure 5. The output of Voltage, Current and power of solar module using filters with sunlight

The use of filters resulted in lowering the module power as compared to its power in the absence of the filters. Red color, in particular, afforded higher current and voltage outputs as compared to the outputs obtained by other colors. The outputs obtained with yellow, green and violet filters were also interesting. Blue colored filter had the least effect on the solar cells outputs affording minimal current outputs as compared to other colors (only $30 \%$ current output) [15].

Solar radiations with wavelengths of $390 \mathrm{~nm}$ to $780 \mathrm{~nm}$ (violet to red) strike the material with enough energy to liberate electrons from their weak bonds and create an electric current. The results of the current study as shown in Table 5 clearly indicated that when filters were used, the PV panel output power was reduced compared to the case without filters. The generated current increased when filters corresponding to long wavelength filters were used. The study results revealed that using colored filters resulted in a general reduction in the performance of solar panels, as could be deduced from Figure 5. However, covering the PV panels with the red colored filter produced the highest reading of the voltage, current and power [16].

\section{EFFECT OF ARTIFICIAL LIGHT SOURCES ON POLYCRYSTALLINE SOLAR CELLS OUTPUTS}

4.1. Effect of Light Source (lamps) on PV/solar Cell Module, and the voltage and current outputs from a solar Panel

The current study aimed at investigating the use of indoor artificial light lamps as an irradiance source for the solar cells. The solar cells were mounted at constant distances from the employed light sources. The experiment was performed in dark conditions using an incandescent light bulb (100 W) and LED lams (15 and $12 \mathrm{~W}$ ) for irradiating the solar panel. Results are presented in Table 6 as shown in Figure 6 (a) and (b).

Table 6. Effect of Different Power Lamp on the Polycrystalline Solar Cells Outputs at Fixed Distance from the Light Source

\begin{tabular}{cccccc}
\hline $\begin{array}{c}\text { Type of lamp } \\
\text { (Watt) }\end{array}$ & $\begin{array}{c}\text { Light intensity } \\
\text { (Lumen) }\end{array}$ & $\begin{array}{c}\text { Distance between lamp and } \\
\text { polycrystalline solar cells (cm) }\end{array}$ & Voltage (V) & $\begin{array}{c}\text { Current } \\
(\mathrm{mA})\end{array}$ & $\begin{array}{c}\text { Power } \\
(\mathrm{W})\end{array}$ \\
\hline Incandescent (100 w) & 150 & 25 & 5.24 & 0.122 & 0.64 \\
LED (15w) & 620 & 25 & 7.46 & 0.22 & 1.6412 \\
LED (12w) & 400 & 25 & 7.23 & 0.12 & 0.87 \\
\hline
\end{tabular}

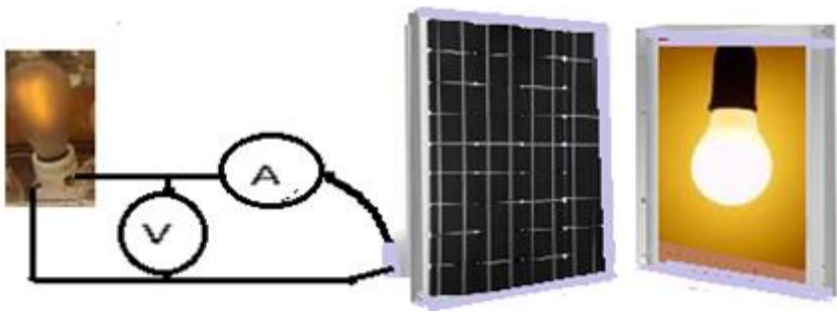

(a)

Figure 6. Other sources of radiation: (a) The assembly used for measurement 


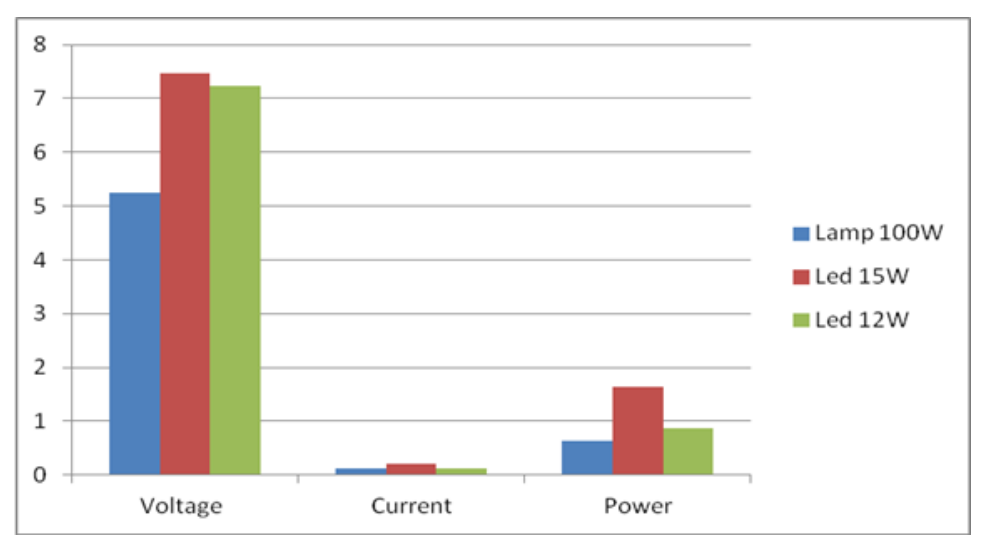

(b)

Figure 6. Other sources of radiation: (b) cell outputs the polycrystalline solar cells outputs

\subsection{Light Color Effects on the Solar Cell Output irradiated with artificial light sources}

The experiment was designed to investigate the effect of colored filters on the indoor irradiated polycrystalline solar cells, using desk incandescent Lamp (5 W), first and then using a compact fluorescent bulbs (LED, 15 and $12 \mathrm{~W}$., respectively). The different lamps were placed at a constant distance from the polycrystalline solar cells. The output results are listed in Table 7.

Table 7. Effect of Color-filter on Cell Output Using a Light Bulb

\begin{tabular}{cccccc}
\hline Filter & Wave length $(\mathrm{nm})$ & Current $(\mathrm{mA})$ & Voltage $(\mathrm{V})$ & Power (Watt) & \% current output \\
\hline Red & $625-780$ & 0.54 & 4.90 & 2.646 & 84.38 \\
Orange & $595-625$ & 0.42 & 4.50 & 1.890 & 65.63 \\
Yellow & $575-595$ & 0.48 & 4.69 & 2.251 & 75.00 \\
Green & $495-575$ & 0.49 & 4.76 & 2.332 & 76.56 \\
Blue & $455-495$ & 0.32 & 4.25 & 1.361 & 50.00 \\
Violet & $390-455$ & 0.44 & 4.66 & 2.050 & 68.75 \\
Without filter & $390-780$ & 0.64 & 5.10 & 3.264 & 100.00 \\
\hline
\end{tabular}

Again, the filters reduced the solar cell outputs as compared to the modules without the colored filters as shown in Figure 7. However, despite that artificially irradiated module with colored filters showed similar response the sunlight irradiated filtered module, it was noticed that the artificially irradiated filtered module had greater current and voltage outputs [17]. In general, the \% current outputs of the artificially irradiated filtered modules were more than $50 \%$ for all colores employed. Particularly, the red filter afforded the maximum $\%$ output (about $84 \%$ current output) while the blue filter afforded the least $\%$ current output $(50 \%)[18]$.

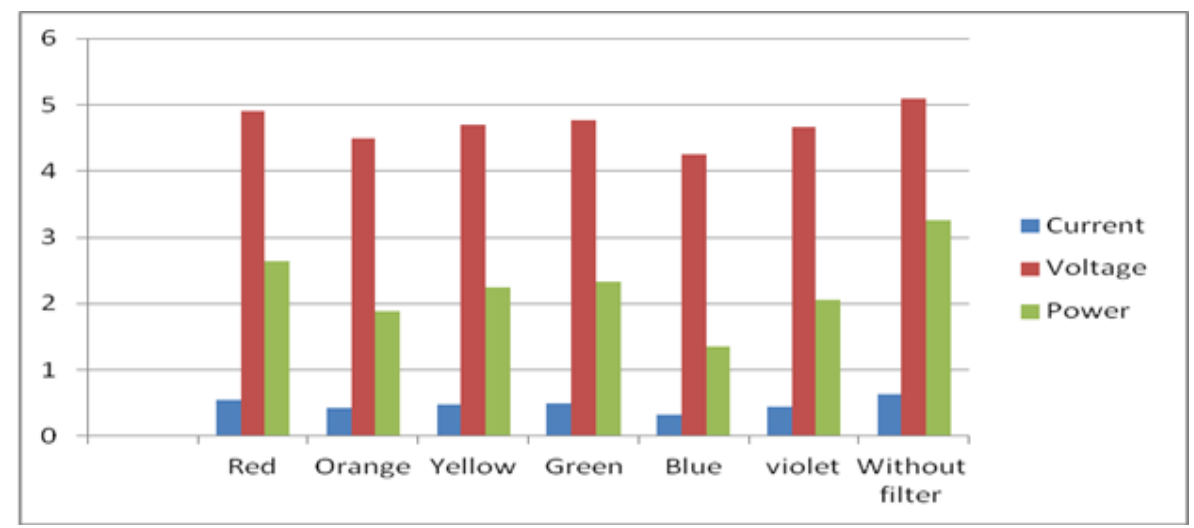

Figure 7. Variation of Voltage, Current and power output of a solar module using filters and a light bulb 


\section{CONCLUSION}

The results of the current study revealed that, in Jordan, the maximum solar cell outputs could be gained during midday, with constant and high outputs expanding a period of six hours during midday, but still other early and late times of sun exposure yielded good outputs. The results clearly indicated that mounting the solar cells perpendicular to sun radiations will afford the best outputs. Additionally, our results were in total agreement with the those obtained by Sudhakar et al (2013) [16] confirming that the use of filters reduced the power, current and output voltage of crystalline solar cells as compared to solar cells without filters. However, greater amount of current was obtained when photovoltaic cells were irradiated with light of longer wavelengths, especially when positioned perpendicular to the radiation source.

However, this case study investigated the possible use of indoor artificially irradiated solar cells, with and without colored filters, aiming to make use of these radiation sources for the production of electricity in shady areas and during the periods where most inhabitants use electricity for indoor enlightening. This period on the average could expand to a minimum of 6 hours a day. This study revealed that exposing solar cells to LED lamps at $25 \mathrm{~cm}$ apart afforded good \% current outputs. Despite that the \% outputs decreased when the solar cells were covered with colored filters, the study indicated that red color had the best \% outputs in terms of current and voltage.

\section{REFERENCES}

[1] Bagher A. M., et al., "Types of Solar Cells and Application," American Journal of Optics and Photonics, vol/issue: 3(5), pp. 94-113, 2015.

[2] S. Sharma, et al., "Solar Cells: In Research and Applications-A Review," Scientific Research, vol/issue: 6(12), pp. 1145-1155, 2015.

[3] F. Outferdine, et al., "Feasibility of Substitution of the Conventional Street Lighting Installation by the Photovoltaic Case Study on a Municipality in Agadir in Morocco," International Journal of Electrical and Computer Engineering (IJECE), vol/issue: 7(5), pp. 2287-2299, 2017.

[4] Dubey S., et al., "Temperature Dependent Photovoltaic (PV) Efficiency and Its Effect on PV Production in the World: A Review," Energy Procedia, vol. 33, pp. 311-321, 2013.

[5] Mohanta P. R., et al., "A Review on Solar Photovoltaics and Roof Top Application of It," International Journal of Advanced Research in Science, Engineering and Technology, vol. 2, pp. 2394-2444, 2015.

[6] A. Pradhan and B. Panda, "Experimental Analysis of Factors Affecting the Power Output of the PV Module," International Journal of Electrical and Computer Engineering, vol/issue: 7(6), pp. 3190-3197. 2017.

[7] G. Apostolou, et al., "Comparison of the indoor performance of 12 commercial PV products by a simple model," Energy science \& Engineering, vol/issue: 4(1), pp. 69-85, 2016.

[8] B. Purwahyudi, et al., "SCNN Based Electrical Characteristics of Solar Photovoltaic Cell Mode," International Journal of Electrical and Computer Engineering (IJECE), vol/issue: 7(6), pp. 3198-3206, 2017.

[9] Rana S., "A Study on Automatic Dual Axis Solar Tracker System using 555 Timer," International Journal of Scientific \& Technology Research, vol/issue: 1(4), pp. 77-85, 2013.

[10] G. Seibert, "Solar cell output as a function of angle of incidence for both unpolarized and linear polarized light," Energy Conversion, vol/issue: 8(3), pp. 121-123, 1968.

[11] A. B. Rao and G. R. Padmanabhan, "Effect of angle of incidence on the performance of a silicon solar cell," Physica Status Solidi (a), vol/issue: 1(1), pp. K29-K32, 1970.

[12] O. Asowata, et al., "Evaluating the effect of orientation angles on the output power of a stationary photovoltaic panel," Journal of Renewable and Sustainable Energy, vol/issue: 6(4), pp. 043114-1-043114-9, 2014.

[13] N. Kumar, et al., "Solar Power Analysis Based On Light Intensity," The International Journal of Engineering and Science (IJES), pp. 01-05, 2014.

[14] Shi D., et al., "Pervoskite/c-Si Tandem Solar Cell with Inverted Nanopyramids: Realizing High Efficiency by Controllable Light Trapping," Scientific Reports, vol/issue: 13(5), pp. 16504, 2015.

[15] K. T. Lee, et al., "Colored dual-functional photovoltaic cells," Journal of Optics, vol/issue: 18(6), 2016.

[16] Sudhakar K., et al., "Effect of color filter on the performance of solar photovoltaic module," International Conference on Power. Energy and Control (ICPEC), pp. 35-38, 2013.

[17] R. G. Ross, et al., "Measurement and characterization of voltage- and current-induced degradation of thin-film photovoltaic modules," Solar Cells, vol/issue: 27(1-4), pp. 289-298, 1989.

[18] A. Khokhar and V. Nandal, "Analyzing the performance of polycrystalline Solar Panel due to the Effect of Color Filters at Different Temperatures \& Different Climatic Conditions," International Journal of Research in Technological Studies, vol/issue: 4(4), pp. 27-28, 2017. 